\title{
The Most Famous Writer of the Low Countries: Herman Brusselmans Star Author and (Reluctant) Public Intellectual
}

\author{
RICK HONINGS
}

Leiden University

Department of Dutch Studies

Universiteit Leiden

P.N. van Eyckhof 3

2311 BV Leiden, The Netherlands

r.a.m.honings@hum.leidenuniv.nl

\begin{abstract}
The Flemish writer Herman Brusselmans is the most famous author of the Low Countries. In this article, Herman Brusselmans is analysed as a star author. First and foremost, two striking aspects of Brusselmans's stardom are analysed: his public visibility and the cult of the private. Attention is then focused on Brusselmans's experience of celebrity, which he - like many other star authors - thematises in his books. Doing so, he consciously places himself in the context of popular culture. On the other hand, as a result of his celebrity status he has been expected - particularly in the last few years - to assume the role of public intellectual willy-nilly, and this in turn has had consequences for his work.
\end{abstract}

Keywords: Herman Brusselmans; Flanders; star author; literary celebrity culture; public intellectual 


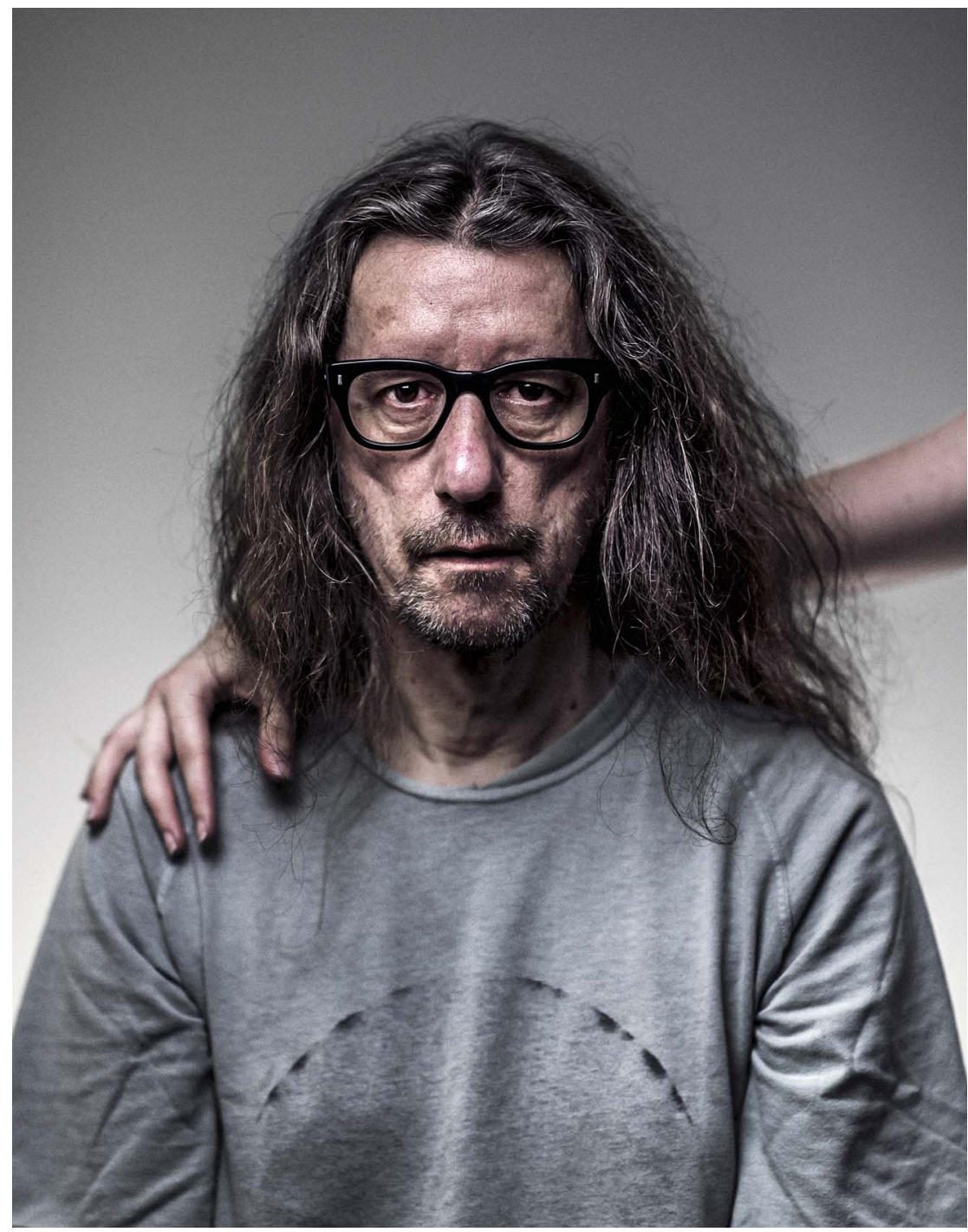

Herman Brusselmans. Photo: Karoly Effenberger 


\section{Introduction}

"I am just about the most famous writer," Herman Brusselmans wrote as early as 1997 and this is no exaggeration. ${ }^{1}$ Due to his striking image - his long hair, the cigarette as his faithful companion and his status as a womanizer and shock author - virtually everyone knows Brusselmans as the famous Flemish writer. Indeed, he literally is Flanders' best-known writer, as a 2013 report by the Center for Reading Research of Ghent University showed, following research among twenty thousand Flemish and five thousand Dutch respondents. These were asked to fill in an online test, where they were presented with a list of fifteen thousand names of published authors and some seven thousand names of people who had never authored a book. And guess what? Not one of the participants did not know Brusselmans. And that made him better known than Hugo Claus, J.R.R. Tolkien and even William Shakespeare. Brusselmans turned out to be the only writer in the Dutch-language area with 100\% name recognition (Brysbaert, Mandera and Keuleers 2013).

Born in Hamme (East Flanders) in 1957, Brusselmans made his debut in 1982 with the short story collection Het zinneloze zeilen [Senseless Sailing] and has since published one book after another in quick succession: stories, plays, poems, novellas and, in particular, a great number of novels. In 2017 his seventy-fifth title was published: Hij schreef te weinig boeken [He Wrote Too Few Books]. What these books have in common is that besides serious passages they are also full of absurdist jokes. Brusselmans is without question a humorous author, which is presumably one of the reasons why he has never been awarded an important literary prize. Yet he boasts a loyal readership who cannot seem to get enough of his books. In 2012 his publisher claimed to have sold over one and a half million copies of his books (Van Eeden 2012: 148). In addition, Brusselmans has written numerous weekly columns for scores of periodicals, ranging from Humo, Het Laatste Nieuws, Playboy, the VARA-gids and Nieuwe Revu to motorcycle magazine ProMotor (on his love for motorcycles) and magazine for dog lovers Woef (about his own dog).

Not only is he an author, Herman Brusselmans is also a media personality. Even people who have never read any of his books, or, for that matter, have never read any book at all and have no intention of doing so, know who he is. This is because he constantly appears in all kinds of television programmes, as a commentator on football matches, for instance (he himself was a semi-professional football player). He is also a regular guest on the Dutch talk show De Wereld

\footnotetext{
1 "Ik ben zo ongeveer de beroemdste schrijver van Vlaanderen" (Brusselmans 1997a: 38). This article is partly based on the first half of chapter 9 of my monograph Majoor van het Menselijk Leed. Leven en werk van Herman Brusselmans (Amsterdam: Prometheus), published in October 2017.
} 
Draait Door and sits on the jury of the popular Flemish television show De Slimste Mens ter Wereld. The latter pays him to make the following type of sick joke: "When I was twenty-two, I was deflowered. I am still grateful to my aunt Sonja, even though she was in a coma at the time." 2

It is not an exaggeration to call Brusselmans a star author, to use Joe Moran's term. In his eponymous 2000 book Moran discusses how in America celebrity has come to play a crucial role in the production and publicity of books. "There is no avoiding authors," Moran correctly observes on the first page of his book. You meet them everywhere: in the Books sections of newspapers and magazines, on television, at festivals, at book signings, but also in places where you might not expect them, like talk shows and television programmes. He situates the start of this development in the nineteenth century, when lecture tours increased public interest in the lives of such famous authors as Charles Dickens, Mark Twain and Oscar Wilde. For the Netherlands too we can trace the beginnings of a modern celebrity and fan culture to that same century (Honings 2016).

Meanwhile, the phenomenon of literary celebrity has become an everyday occurrence, however paradoxical the notion may seem. Literature is traditionally classified as highbrow culture while the world of celebrity, showbiz and entertainment is ranked with popular or lowbrow culture. A literary writer is expected to have moral authority, to see a role for himself in the public discourse; he ought to have little affinity with the entertainment industry attendant on the world of the celebrity. Yet the phenomenon of literary celebrity is ubiquitous. Authors like Bret Easton Ellis, Haruki Murakami and J.K. Rowling have gained worldwide star status: they rub shoulders with or belong to the world of celebrity culture and they are at the same time associated with high culture.

This tension is also central to the research into literary celebrity that has been emerging over the past few years. Its focus is especially on Anglo-American literature and on famous canonical authors from Britain and the Unites States. Two periods in particular have received a great deal of international attention: the $19^{\text {th }}$ century and the Modernist period. The relation between literary celebrity and gender has similarly been addressed in several publications. Lately the subject has increasingly received attention in the Netherlands, too. ${ }^{3}$

It is no overstatement to say that Brusselmans too is a celebrity author in whom - and in him more so, perhaps, than in any other author in the Dutch-language area - this highbrow and popular culture are united in one person. Where else can we find intertextual references to James Joyce, J.D. Salinger, Gerard Reve, play with autobiography and metafiction, and, at the same time, comments on

\footnotetext{
${ }^{2}$ Check YouTube, with the search terms: 'Herman Brusselmans' and 'Slimste Mens.'

${ }^{3}$ For a broad overview on this subject see (Franssen and Honings 2016) and (Franssen and Honings 2017).
} 
people in the entertainment industry? Brusselmans's active involvement in the world of entertainment has contributed to academe's failure to study him and his work. Dimitri Verhulst was correct to point out the extreme extent to which Brusselmans is ignored by the "notorious literary experts" with their "blessed opinions" (Verhulst 2001). ${ }^{4}$ Little has changed since then.

The present article analyses Herman Brusselmans as a star author. It is important to emphasize here that he is almost completely unknown outside the Dutch-language area. Over time his work may sporadically have been translated, into German, French, Italian and Hungarian, yet his fame does not stretch beyond the Netherlands and Flanders. ${ }^{5}$ He differs in this respect from such authors as Bret Easton Ellis, Haruki Murakami or J.K. Rowling.

All the same, there is justification for analysing him from the perspective of celebrity. This will not, however, involve a detailed reconstruction of his many hundreds of media appearances. First and foremost I would like examine two striking aspects of Brusselmans's stardom: his public visibility and the cult of the private. Attention is then focused on Brusselmans's experience of celebrity, which he - like many other star authors - thematises in his books. Brusselmans will not pass up an opportunity to stress that his work only serves to entertain. Doing so, he consciously places himself in the context of popular culture. On the other hand, as a result of his celebrity status he has been expected - particularly in the last few years - to assume the role of public intellectual willy-nilly, and this in turn has had consequences for his work. This aspect is analysed in section 4 .

\section{Public visibility and the cult of the private}

An important, if not the most important, feature of a celebrity in general and a literary celebrity in particular is his or her public visibility. Anyone seeking fame must be in the public eye. It is not for nothing that sociologist Robert van Krieken (2012: 61) characterises celebrities (whether footballers, actresses or authors) as "larger or smaller bundles of attention-capital." Their being in the spotlight is exactly what makes them famous. Brusselmans too is highly visible: he performs in bookshops, at the Antwerp book fair and at literary festivals and events. In 2017 he was even one of the acts at the big music festival Lowlands. He also gives interviews on an almost weekly basis for Dutch and Flemish newspapers, magazines, radio and television and he regularly goes on tours - in 2016-2017 as part of the Saint Amour tour organised by Behoud de Begeerte. He is, moreover, one

\footnotetext{
4 "notoire literatuurkenners" met hun "gezegende meningen."

${ }^{5}$ For an overview of Brusselmans's translations see www.vertalingendatabase.nl.
} 
of the night writers: an initiative by the writer Kluun to have Dutch and Flemish authors perform on the stages of nightclubs and theatres. Hardly a day goes by that Herman Brusselmans is not, one way or other, in the spotlight.

Nowadays authors use (social) media like Facebook, Twitter, Instagram and YouTube to constantly draw attention to themselves. In the mid-1980s Brusselmans made a name for himself as a writer, especially after the publication of his novel De man die werk vond [The Man Who Found a Job, 1985]. This work earned him the status of a cult author. However, it was not until the 1990s that he made a breakthrough with the general public. Yet whatever point in time is taken as the start of Brusselmans's fame, the fact is that at the time there was not yet any Internet or social media. He achieved fame, then, in the pre-Internet era and, in actual fact, that is where he still is. Unlike many others, he does not have his own website. And Brusselmans wants nothing to do with Facebook, Twitter or Instagram, either. The conservative attitude he has adopted with regard to social media is very much a conscious one. He thus distances himself emphatically from one of the most striking aspects of twenty-first century celebrity culture.

However, this is not to say that Brusselmans cannot be found on the Internet. Not a day goes by without messages about him being placed on Twitter, usually about three or four a day: selfies with and photos of the writer, announcements and invitations to public performances in libraries, bookshops and at literary manifestations, reactions, pictures of look-a-likes, latest news, links to interviews, comments about football, literature, women, and so on and so forth. Since March 2017 there has even been a tweeter who uses the name Herman Brusselmans. Still, it is not so much the Internet as television that has made his name. Joe Moran (2000: 37) also connects an author's celebrity with the level of his screen presence. In Brusselmans's case this can be said to be excessive. Simply enter his name on YouTube and see how often - hundreds of times - he has appeared on Flemish and Dutch TV over the past decades.

The first time Brusselmans appeared on the box was on the occasion of his debut Het zinneloze zeilen (1982). Since then he would present himself regularly on television. He appeared, for instance, on the Flemish TV programme Wie schrijft die blijft, where his performance in the Brussels Centre for Fine Arts was broadcast on 5 March 1988. The broadcast gave him the opportunity to present his image to the general public. He was dressed in jeans and a leather jacket, sported a plaster on his cheek and had a can of Jupiler beer with him. He reached a large audience with his appearance on the Veronica programme RUR on Dutch TV in 1988. He was called an "Angry Young Belgian" by talk-show host Jan Lenferink and his talent for humour was given free rein. In the three months following the show ten thousand copies of the pocket edition of De man die werk vond were sold (Hendrickx 1988). 
Although Brusselmans could still occasionally be seen on TV in the 1980s, it was above all during the 1990s that he became a Flemish Celebrity. In 1992 he hosted, together with Walter Grootaers, the programme De laatste mannen for Radio Donna, which only ran for one season. At that time he also appeared regularly on television. In the 1991-1992 season, for instance, he presented a popular part of the much-watched Flemish television programme Het Huis van Wantrouwen, which was shown every Thursday night. In his feature "Klare taal" [Clear Language] the long-haired, smartly-suited writer read a humorous, pun-filled column for a few minutes ("A.C. Milan Kundera"), where he kept saying "Doch dit alles terzijde" ["But all this is by the by"] and ended his performance with "Dank u voor uw wáándacht" ["Thank you for your rattention"]. This was the slogan to make him famous.

In the wake of this programme - watched every week by two million viewers - he received several offers. One of these involved a radio commercial for the fashion chain Superconfex. In 1995 he went on tour, together with Luc De Vos and Hugo Matthysen as part of the Geletterde mensen series of Behoud de Begeerte. He subsequently appeared with Jo Van Damme on the BRTN programme De Zeventien Meter. In 1996, moreover, he had a supporting role in the comedy Camping Cosmos. Two years earlier, he had acted in the film La vie sexuelle des Belges, 1950-1978, where he is seen drinking beer and shouting "fuck you." In brief, Brusselmans has been consistently seizing the spotlight as a media figure.

Little has since changed in that he is still a welcome guest on numerous programmes. Hardly a week goes by without Brusselmans appearing on TV. Just as he does not seem to distinguish highbrow from lowbrow in his work, so he similarly does not make the distinction on TV either. He appears in programmes on literature and, with equal ease, in shows that have nothing whatsoever to do with literature or his work as an author. He is a regular guest, for instance, on the Flemish programme Studio 1, where, as a former football player, he gives his unvarnished opinion on football and related matters. Or he turns up as a jury member in De Beste Singer-Songwriter van Nederland, where he is expected to quip about the performances. And, as already noted, he is one of the jury members on the popular Flemish television programme De Slimste Mens ter Wereld, where his sick jokes have the presenter and the audience in laughing fits that last for minutes. In 2017 he was one of the guests on the programme Mag ik u kussen?, where three men try to win the hand of a Flemish celebrity with their witticisms and jokes. And many more programmes could be added to these where Brusselmans appears as an entertainer. It is primarily a way of earning a lot of money, as he likes to say.

But even programmes on which Brusselmans the writer is invited to talk about his latest book, for example, mostly end up as a bizarre cocktail of highbrow and 
lowbrow, with the balance frequently tipped in favour of the latter. By way of example: the number of times he could talk seriously about his authorship and his work on the TV show De Wereld Draait Door can be counted on the fingers of one hand. It is truly unique when his work as an author receives serious attention.

The writer is well aware that television has played a crucial role in the construction of his fame. The effects are not only positive, however. People tend to forget that he is first and foremost a writer. In an interview held in 2010 he stated: "Here, on the streets of Ghent, many people know who I am. Ah, right, the chap with the long hair, the glasses, the pock-marked face. But I think that only about one in twenty make the connection with literature." In his younger years he might have said that it was important that his books, rather than himself, were famous but he has long since rowed back from that idea: "If you appear on TV plenty of times, you automatically become famous" (Dijksman 2010). ${ }^{6}$

In 2017 Brusselmans observed: "People are no longer famous first and then appear on TV but they are famous because they appear on TV" (Vakmansklap 2017). ${ }^{7}$ But the writer does not seem to realise that this is also true for himself, since the majority of the audience apparently does not know him as a writer but, rather, as the long-haired Flemish celebrity so often seen on TV. This ties in with the fact that his work is little studied. Because of his screen presence, he is seen as an author who primarily belongs with lowbrow culture. Surely, someone who talks all sorts of nonsense on TV all the time cannot be a serious writer? This is presumably one of the reasons why he has never been awarded a literary prize yet.

Obviously, Brusselmans himself is partly responsible for this: in both his public performances and in his literary work he constantly rubs shoulders with the glitter and glamour of the world of entertainment. Brusselmans is only too pleased to be accompanied to book presentations by such famous beauties as Miss Belgium. And there is his well-known appeal to Dutch actress Carice van Houten, whom he claimed to have fancied for a long time. He even had a short film made calling on her to contact him. In 2012 a racy photo shoot with her finally took place for Nieuwe Revu. Afterwards, they had a cup of coffee, and this was at once grist to the mill of De Telegraaf: "Brusselmans had date with Carice van Houten" (4 March 2014). In his novels he also frequently refers to famous actresses.

A second feature of a star author that is connected with screen presence concerns the boundless fascination shown for his private life. This definitely applies to Brusselmans. A partial explanation is that he publishes (semi-)autobiographical books, but this does not suffice. Both as a writer and as a media figure

\footnotetext{
${ }^{6}$ "Hier op straat in Gent weten veel mensen wel wie ik ben. O ja, die met dat lange haar, die bril, dat pokdalige gezicht. Maar ik denk dat maar pakweg één op de twintig van die mensen de link met de literatuur legt," "Als je maar vaak genoeg op tv komt, word je automatisch beroemd."

7 "Mensen zijn niet meer beroemd en komen daardoor op tv, maar ze zijn beroemd omdat ze op tv komen" (Interview Vakmansklap, 12.03.2017, on YouTube).
} 
Brusselmans is so ubiquitously present that the media feel an urge to go behind the mask and report on his private life. This practice has developed in particular over the past fifteen years, from about the time that he was summoned to appear in court for insulting a well-known fashion designer in Uitgeverij Guggenheimer [Publisher Guggenheimer] (Hupe 2016). In Brusselmans's case there is undoubtedly a correlation between celebrity and scandal: the very fact that he mocks Flemish celebrities from the Flemish entertainment world in his Guggenheimer books has made him a part of that world, where celebrity gossip about the lives of the stars is the order of the day.

Brusselmans is well known for his love of dogs. When in 2006, two years after the death of his previous dog, he decided to buy another one, a great many media carried the news. "Herman Brusselmans has new dog," read the headline in Het Nieuwsblad, followed by a short interview. In 2011 Brusselmans's wife Tania de Metsenaere left him. This too immediately became big news. "Herman Brusselmans and muse Tania break up," it said in the Gazet van Antwerpen, while De Standaard reported the news thus: "Herman Brusselmans and Tania living apart." Het Laatste Nieuws, finally, produced this headline: "Herman Brusselmans now in LAT relationship." After his disclosure, in Poppy en Eddie [Poppy and Eddie, 2014], that Tania had breast cancer, the Flemish press had a field day. HUMO, for one, carried a long interview with the author that almost exclusively centres around private questions like: "How is she now?", "Has Tania's illness brought a new intimacy?" and "Your muse is no longer your love. Don't you still feel that's sad?" (Maris 2014). ${ }^{8}$

After his split with Tania, the maelstrom that his love life then became took centre stage again. He appeared on De Wereld Draait Door in 2012 after the publication of Guggenheimer in de mode [Guggenheimer in Fashion] but this was merely a pretext for the programme to have another chat with the writer. Apart from a mention of the book's title during the introduction of the writer, his work hardly came up in the seven-and-a-half-minute item. The only thing apparently to interest presenter Matthijs van Nieuwkerk was the author's private life. His wife had left him two years earlier and the search for a new love had not yet yielded results, the presenter remarked. And so, the following question was warranted: "How is one of the Handsome Young Gods of Flemish letters doing?" From there on, the whole item turned on his sorrows, his attractiveness in particular to young girls and other private matters.

When in 2013 he started a relationship with Melissa Janssens, who was then twenty-five years old, the media reporting was extensive, both in Belgium and the Netherlands, with the age difference being stressed time and again. The

\footnotetext{
8 "Hoe gaat het nu met haar?"; “Is er door de ziekte van Tania een nieuwe intimiteit gekomen?"; "Je muze is niet meer je lief. Blijf je dat niet sneu vinden?".
} 
headline in the Algemeen Dagblad is especially telling: "Melissa Janssens (25) new flame Brusselmans (56)." And when they split up again a year later, this too was material for the gossip pages, ranging from Nieuwe Revu and De Telegraaf, to HUMO and De Standaard. Obviously, his new relationship with Lena, with whom he appeared side by side for the first time when presenting De fouten [The Mistakes, 2016], was again commented on extensively, even in magazines that normally shun literary subjects, like Linda: "Herman Brusselmans (58) in love again with a young thing (24)". Such one-sided, personal interest-focused reporting and interviewing are typical of Brusselmans's star authorship.

\section{The experience of celebrity}

The phenomenon of star authors thematising their own celebrity status in their own works is not unusual in international literature. Joe Moran $(2000: 69,74)$ has this to say on the subject: "Many critics have seen the current vogue for autobiography and autobiographical fiction by authors, often dealing with their own fame, as a pernicious effect of celebrity culture." He adduces Bret Easton Ellis as an example of star authors writing about being famous and thus deploying their work "as a form of self-promotion, a seamless by-product of their celebrity." World literature abounds with such examples. Dutch literature likewise boasts authors who attest to their experience of celebrity, including Herman Brusselmans. He too thematises being famous in much of his oeuvre and he too uses writing about his fame as a strategy to promote himself with the reader. Brusselmans's tactic is to emphasise but also exaggerate and fictionalise his own cult status as a famous author.

When read in chronological order, Brusselmans's books inform us about his development and life as a famous author. The subject does not yet feature in his works from the 1980s: he was only a marginal writer at that time. It is only in Zijn er kanalen in Aalst? [Are There Canals in Aalst?, 1987] that the first signs are discernible: towards the end of the novel its main character, Eduard Kronenburg, resolves to acquire fame by becoming the best Flemish writer ever, and it is then that he styles himself a "Mooie Jonge Oppergod" ["Handsome Young Super God"] (Brusselmans 2005a: 178). A similar bravado tone characterises the novella Iedere zondag sterven en doodgaan in de week [Passing Away Every Sunday and Dying in the Week, 1988] where he emphatically presents himself as a famous author: "The toll of fame began to weigh heavily on him. Not a minute's rest anymore" 9 (Brusselmans 1988: 17).

\footnotetext{
9 "De tol van de roem begon hem zwaar te wegen. Geen minuut rust meer."
} 
It was in his novel Dagboek van een vermoeide egoist [Diary of a Jaded Egoist, 1989], however, that his celebrity status became an explicit subject. He gets talking with a boy and a girl in the pub. The girl has never heard of him, but his name rings a bell with the boy: "Hang on. Weren't you on television the other day? You were drinking Palm beer all the time and at the end you did nothing but burp" (Brusselmans 2006a: 225). ${ }^{10}$ Brusselmans, then, is recognised because of his screen presence and not, to his regret, because of his authorship. This is a motif that we will encounter more often in his later novels.

From then on, Brusselmans would bring up his experience of celebrity more and more often. In Ex-drummer [Ex-Drummer, 1994] the I persona is invited to join a band because the other members are fans of him: "Because of your books, your TV and radio appearances, and your interviews in the papers, that sort of thing, you know, your fame" (Brusselmans 1994: 14). ${ }^{11}$ In Het mooie kotsende meisje [The Pretty Puking Girl, 1992] the protagonist sighs: "Yes, I am slowly becoming famous. People in the street are even beginning to recognize me," adding a typically Brusselmansesque qualification: "albeit for the time being only in the Leeuwstraat, where I live also myself as well" (Brusselmans 1992: 27). ${ }^{12}$ By the mid-1990s he had become a real star author, as he does not fail to emphasize. In 2004 he even published the novel Ik ben rijk en beroemd en ik heb nekpijn [I'm Rich and Famous and Have Neckache, 2004]. Yet he also pokes fun at himself as a famous author. He notes, for instance, in Bloemen op mijn graf [Flowers on my Grave, 1998] that he is now the most famous writer in Belgium and the Benelux as well as a sex symbol, but that his life is far from perfect: "I've been incontinent as hell for a while now. Shat my trousers twice today and as many as three and a half times yesterday!" (Brusselmans 1998: 89). ${ }^{13}$

That Brusselmans developed into a Flemish celebrity thanks to his many television appearances in the early 1990s resulted in him being treated as such, even though the writer did not shy away from constantly exaggerating the impact of his fame and turning this into a literary subject. From that moment to the present day, several motifs can be seen to recur in his novels that are connected with his status as a star author.

First, he recounts in his work how he is recognised in the street and in other public places. There is hardly a book in Brusselmans's oeuvre that does not

\footnotetext{
10 “Wacht's even. Ben jij laatst niet op televisie geweest? Je zat de hele tijd Palm te drinken en aan het eind deed je niks anders dan boeren."

11 "Door je boeken, je optredens op tv en radio, en je interviews in de kranten en zo, je weet wel, je beroemdheid."

12 "Ja, ik ben langzamerhand beroemd aan het worden. Men begint mij zelfs al te herkennen op straat"; "zij het voorlopig alleen in de Leeuwstraat, waar ik zelf ook woon."

${ }_{13}$ "Zo ben ik al een tijdje zo incontinent als de pest. Vandaag al twee keer in mijn broek gekakt en gisteren maar liefst drieënhalve keer!"
} 
contain this motif. Yet it turns out once more that people see him as a TV personality first and as a writer second, as in Ex-minnaar [Ex-Lover, 1993], where a character exclaims: "Bloody hell, mate, you were brilliant on TV! When are they going to do that programme again?" (Brusselmans 1993: 11-12). ${ }^{14}$ In Autobiografie van iemand anders [Autobiography of Someone Else, 1996] a girl remarks that she knows him from television, at which the I persona sighs: "From TV? Did she really say from TV? Instead of: author of twenty books about Life Itself which have altogether sold a cool half a million copies while he is still only thirty-eight, you know?" (Brusselmans 1996: 102). ${ }^{15}$ In Vergeef mij de liefde [Forgive Me the Love, 2000] he is totally fed up: "TV can kiss my arse. I am a writer. I don't want to be stared at, I want to be read" (Brusselmans 2000: 516). ${ }^{16}$

Even so, there are a few times that the Brusselmans persona is recognised for his authorship. In Autobiografie van iemand anders, for example, a girl on the train confesses to him that she has read eight of his books. Instead of being flattered, however, he feels disappointed because this means there are at least ten works that she has not yet imbibed. It also happens frequently in his work that a character calls himself a fan of his as a writer but is then unable to mention even a few titles (or gets muddled up when listing them). Occasionally, the I persona is also recognised by large groups, for instance when a canal cruise boat passes while he is staring out of the window and the guide points him out: "There, behind that window, you can see the famous writer Herman Brusselmans" (Brusselmans 2002: 613). ${ }^{17}$

Having to sign autographs is another consequence of being famous that Brusselmans describes regularly. Vlucht voor mij [Run from Me, 1989] presents the first instance in his work where he is accosted by a young man asking for his autograph. However, he refuses, adding that he has given plenty of autographs: "In the past I never dared put off those buggers, but now I do" (Brusselmans 2006b: 189). ${ }^{18}$ Usually the author is more forthcoming in this respect. When asked, he presents many a fan with his scribble.

A third and final aspect of Brusselmans's fame that is thematised over and over again is having groupies. In De kus in de nacht [The Kiss in the Night, 2002] he claims to be a phenomenon and a cult god: "I get underpants dripping, I evoke feelings of hatred and hysterics, I have the most fanatical and dogged admirers and detractors a Dutch writer has ever had" (Brusselmans

\footnotetext{
14 "Godverdomme makker, jij was fantastisch op die tv! Wanneer begint dat programma weer?"

15 "Van op tv? Zei ze werkelijk van op tv? In plaats van: schrijver van twintig boeken over Het Leven Zelve waarvan alles samen zo'n slordige half miljoen exemplaren verkocht zijn terwijl hij nog maar pas achtendertig is moet je meerekenen?"

16 “De tv kan m'n kloten kussen. Ik ben een schríjver. Ik wil niet bekeken worden, maar wel gelezen."

17 "Daar, achter dat raam, zie u de beroemde schrijver Herman Brusselmans."

18 "Vroeger durfde ik dat soort zeikerds nooit af te schepen, maar nu wel."
} 
2002: 432). ${ }^{19}$ It is especially girls who thrust themselves on the famous author as his fans. Since his appearance on television he has written about the effect of his fame on women. In his novels Brusselmans makes it appear as if he too is constantly being besieged by girls. By his own account, he is flooded with mail from female fans. As early as Ex-schrijver [Ex-Writer, 1991] he published a (fictitious?) fan letter from a Dutch girl: "Dear dear dear H., I am a fan, but my parents won't let me read your books, but I read them anyway because I love you" (Brusselmans 1991: 161-162). ${ }^{20}$ It is thus that he has cultivated his celebrity status and propagated his image as an idolized author.

This would not be the last time that he wrote about fan mail. In Autobiografie van iemand anders (1996), for instance, he cites a love letter from a girl who claims to have fallen for the I persona in his books. And in Zul je mij altijd graag zien? [Will You Love Me Forever?, 1997] he writes about the mail he has received in response to his work: "The fan mail that I got! Kilos of it. Heavy stuff." A few female readers have even asked him if he wanted to sleep with them and "all of them were asking to play the role of victim in my next book." (Brusselmans 1997b: 15). ${ }^{21}$

The makers of the Flemish television programme Chris $\mathcal{E}$ Co, where Brusselmans is parodied by Chris Van den Durpel, poke fun at these fantasies. The writer is seen sitting at his computer when the doorbell rings. It is the postman delivering a registered letter. In Brusselmans's universe this event assumes mythological proportions: "My front door was besieged by a horde of female fans. They all wanted an autograph. After the signing session I quickly yet resolutely went through my fan mail." ${ }^{22}$ This is how Brusselmans's image is ridiculed by the author himself. His writing about the female fans seems, indeed, a bit much: it reinforces the image of the celebrity author.

But fan mail is not where Brusselmans holds back in his work. Women allegedly faint as soon as they see the author and they thrust themselves en masse on him. As early as Vlucht voor mij he writes about "a horde of babes around my neck whispering that they may be in love with me and that sort of thing" (Brusselmans 2006b: 28). ${ }^{23}$ Ultimately, though, "the deed" is never done with groupies in Brusselmans's work. As much is clear from Vergeef mij de liefde, where I per-

\footnotetext{
19 “Ik breng onderbroeken aan het druppelen, ik roep gevoelens van haat en hysterie op, ik heb de fanatiekste en hardnekkigste bewonderaars en tegenstanders die een Nederlandstalige schrijver ooit gekend heeft."

${ }_{20}$ "Lieve lieve lieve H., ik ben een fan, maar ik mag uw boeken niet lezen van mijn ouders, maar ik doe het toch want ik zie u graag."

21 "Fanmail dat ik kreeg! Met kilo's. Zware kost"; “met z'n allen solliciteerden ze naar een rol als slachtoffer in m'n volgende boek."

${ }_{22}$ "Mijn voordeur werd bestormd door een horde vrouwelijke fans. Zij wilden allemaal een handtekening. Na de signeersessie nam ik vlug doch vastberaden mijn fanmail door" (Chris \& Co, "Herman Brusselmans en de teef", on YouTube).

${ }_{23}$ “een hele bende wijven rond $m^{\prime} n$ nek die me toefluisterden dat ze misschien wel verliefd op me zijn en dergelijke toestanden."
} 
sona Herman Brusselmans is interviewed by a girl, Sandy, who is racked with nerves: “Sorry, Herman. It's just, I'm so terribly nervous. You are so famous and I am nobody. I'm just a girl." Then the writer invites her to undress and some wild love-making ensues. But as she is about to remove his jeans, he feels she has gone too far: "I am monogamous. Only my wife can see my dick" (Brusselmans 2000: 28-29). ${ }^{24}$ And that, obviously, heightens the star author's mystery.

What function, then, do these many descriptions of his fame and its effects serve? The endless boasting about being recognised, the requests for autographs and the descriptions of randy female fans are all part of the bravado-filled Brusselmans cult, meant to drown out and mask his fears. We often get to see this sombre, insecure side of his character in his semi-autobiographical books when he retreats from the public space to hole up in the safe cocoon of his house. But there is another thing: self-promotion is definitely also at play in Brusselmans's case (as in the case of Bret Easton Ellis, mentioned by Moran). That Brusselmans time and again writes about how famous he is, even while making it very clear that his accounts are largely fictionalised, has in actual fact contributed to his being accorded that status. In this way he himself has to a large extent promoted his fame and image as a star author with groupies.

Brusselmans has repeatedly expressed a wish to withdraw from public life in his work and in interviews. This too is not uncommon in star authors, as Joe Moran (2000: 79) writes that many famous authors "seek to locate a 'private' self [...] beyond celebrity." As early as Zul je mij altijd graag zien? he resolves henceforth to stay out of the spotlight and not do any more performances (Brusselmans 1997b: 128). And in Kaloemmerkes in de zep [Tadpoles in the Gutter, 2009] he talks about this dream never to have to do interviews again: "A hermit is what I'd like to be, like Thomas Pynchon, J.D. Salinger or Ward Ruyslinck" (Brusselmans 2009: 117). ${ }^{25}$ According to Moran (2000: 79), celebrity authors, whether they like it or not, remain "implicated in the systems and practices through which their fame is produced." This is also true for Herman Brusselmans. Ultimately, a star author cannot get away from fame.

\section{Brusselmans as public intellectual?}

Literary celebrity also carries obligations, whether a writer likes it or not. As an author acquires a certain position, he automatically develops into a cultural authority. And this position gives him - however paradoxical this may initially

\footnotetext{
24 "Sorry, Herman. Het is alleen, ik ben zo enorm zenuwachtig. Jij bent zo beroemd en ik ben niemand. Ik ben zomaar een meisje"; "Ik ben monogaam. Alleen m'n vrouw mag m'n lul zien." 25 "Een kluizenaar wil ik worden, zoals Thomas Pynchon, J.D. Salinger en Ward Ruyslinck."
} 
seem - a window to vent his opinions on issues other than literature. Many do not shy away from taking part in the public debate. So doing, they acquire the status of public intellectual.

Odile Heynders, who published a book about Writers as Public Intellectuals. Literature, Celebrity, Democracy (2016), characterises the public intellectual as someone on the sidelines who takes part in the public debate with provocative views: "He has critical knowledge and ideas, stimulates discussion and offers alternative scenarios in regard to topics of political, social and ethical nature, thus addressing non-specialist audiences on matters of general concern" (Heynders 2016: 3). Various channels are open to him: lectures, letters to the editor, articles or documentaries. In recent years, the Internet has increased the possibilities for authors to show their engagement. They use blogs, Twitter and Facebook to put across their viewpoints. In her introduction Heynders (2016: 3, 12-15) makes a connection between public intellectuals and celebrity: their fame lends them the authority to speak out and this, in turn, makes them even better known. It is thus, she argues, that the paradoxical identity of the celebrity intellectual has come about. A Dutch example of a celebrity intellectual is Arnon Grunberg, who regularly brings his cultural authority to bear on public debate, as, for instance, in his daily column "Voetnoot" on de Volkskrant's front page (Heynders 2012).

"Public intellectual" is a rather unlikely epithet for Herman Brusselmans: he is usually non-committal about political, social or ethical issues. When he appears on television, serious subjects are few and far between. Since 2016 Brusselmans has been writing weekly columns in the "Koppensneller" [Headhunter] section of HUMO: pieces in response to a recent headline that has caught his attention. Yet even here, he rarely, if ever, deals seriously with a subject. The headlines merely serve as triggers for him to chatter on about nonsense, although there have been a few exceptions, like a 2017 column about the child victims in Syria, where he writes, among other things, that Assad's wife is a looker, but ends the piece with: "We have gone beyond all jokes, we are beyond everything" (Brusselmans 2017a). ${ }^{26}$

That Brusselmans hardly, if ever, shows his engagement is connected with his view that literature is merely meant to entertain. He used to share this vision with Tom Lanoye, i.e. the young Lanoye, with whom he hung around in his early years as a writer. But where Lanoye gradually became increasingly more engaged and moralistic, Brusselmans held on to his old adage that literature is no more than entertainment. "There is only one rule: a book should entertain," he remarked in NRC Handelsblad in 1999 (Takken 1999). ${ }^{27}$

\footnotetext{
26 "We zijn alle grappen voorbij, we zijn alles voorbij."

27 "Er is slechts één regel: een boek moet amusement bieden."
} 
The difference of opinion between Brusselmans and Lanoye is beautifully illustrated in the HUMO columns that the former published in Het mooie kotsende meisje (1992), and which he wrote for some time in the early 1990s while replacing permanent columnist Lanoye. Brusselmans seized the opportunity to vent his poetical ideas albeit in a non-serious way. As early as his first contribution, "Tom Lanoye ad interim," he stated that his colleague had well-informed and well-founded opinions about all sorts of topics like "let's say, the influence of the interaction between awakening homosexuality and the electoral surge of the Vlaams Blok on the poetry by young Antwerp poets in 1992 and thereafter." His own view on the matter was that he had no opinion. And that, he explained, had everything to do with his philosophy of life, which was: "What the hell do I care." To which he added: "And this sort of outlook on life doesn't really get you anywhere when we're talking well-considered opinions" (Brusselmans 1992: 173-174). ${ }^{28}$

It is clear: in contrast to Lanoye, Brusselmans refuses to assume the role of public intellectual. He has stressed as much in numerous interviews, as in 1998 in De Morgen, where he gave his thoughts on Lanoye's engaged authorship: "Tom is a fantastic artist and an absolute friend but what has got into him? Does a writer have to do politics? I think that's an absolutely ridiculous discussion." Brusselmans has termed writers wanting to engage in politics with their work, "absolute twits" and "non-writers" (Rogiers and Heene 1998). ${ }^{29} \mathrm{He}$ contrasts them with his literary heroes J.D. Salinger and Charles Bukowski, who he feels expressed their disaffection with the world in a non-intellectual way.

Four years later, he expressed the same viewpoint in the television programme Nachtwacht (2002), where he discussed the question of what literature is with Lanoye and Kristien Hemmerechts. Lanoye presented himself as a man of the theatre and stage manager but also as someone who considers it important to comment on the state of the world. This elicited Hemmerechts's remark that Lanoye could just as well have become a politician yet had apparently chosen to be a writer. In this company, Brusselmans and Lanoye were clearly poles apart. The former explained to the interviewer that he did not mean his work to say or convey anything, least of all about the world around him. His only aim was to fill empty pages and write, preferably, a thousand books. De kus in de nacht (2002) has this observation about literature: "It doesn't

\footnotetext{
28 "ik noem maar wat, de invloed van de interactie tussen ontluikende homoseksualiteit en de electorale vooruitgang van het Vlaams Blok op de poëzie van jonge Antwerpse dichters in 1992 en later;" "Wat kan het mij in godsnaam allemaal schelen;" "En met dat soort levensfilosofie schiet je niet veel op als het gaat over het hebben van weldoordachte meningen."

${ }^{29}$ "Tom is een fantastische kunstenaar en een absolute vriend, maar wat bezielt hem? Moet een schrijver aan politiek doen? Ik vind dat een absoluut onzinnige discussie," "absolute minkukels" en "non-schrijvers."
} 
make any difference what a writer writes. It won't stop wars, or end famines, people will continue to travel, and there are even more floods and heat waves now than before I made my debut with Het zinneloze zeilen" (Brusselmans 2002: 417). ${ }^{30}$

Yet it is not true that current political-social events never play a role in Brusselmans's work but they are always kept in the background, without judgment being passed on them. As in Ex-schrijver (1991), where the I persona sees an item about the Gulf War on television. By way of protest, he straightaway turns off the television: "What bullshit was this. What has the whole shit got to do with me, for god's sake? Leave me alone" (Brusselmans 1991: 244). ${ }^{31}$ The only thing that interests him is his own life, the pointlessness of which is thus underlined all the more. And in a column the author addresses the over-35s, a group to which he himself also belonged:

Your engagement with world suffering has become a laugh: what the hell do you care whether Bosnians have or have not stopped shooting Croatians to a pulp, or the other way around, or Palestinians Jews, or vice versa; what the hell do you care that everyday a bunch of stupid Negroes still starve to death; what the hell do you care that the extreme right is copying its advance of 1933; what the hell do you care who will be the new President of America. (Brusselmans 1998: 117) ${ }^{32}$

Other politically or otherwise sensitive topics are also touched on by Brusselmans, but merely as asides. The main protagonist of Logica voor idioten [Logics for Idiots, 1997] accidentally ends up in a conversation about Marc Dutroux, but after just one sentence the conversation reverts to cars (Brusselmans 1997a: 49). In De kus in de nacht George W. Bush turns out to have been elected President of the US. Although the I persona would have preferred Al Gore in that position, it is ultimately all the same to him. If someone were to ask him how he saw America's role in the world, he might say: "Oh piss off asshole." Even if America were to be wiped off the map, it would not keep him awake: "Do you think I will eat one peanut butter sandwich less? Well, possibly, I don't like peanut butter anyway" (Brusselmans 2002: 59-60). ${ }^{33}$

\footnotetext{
30 "Het haalt niks uit wat een schrijver schrijft. De oorlog houdt niet op, de hongersnood gaat niet weg, de mensen blijven reizen, en er zijn zelfs meer overstromingen en hittegolven dan voor ik debuteerde met Het zinneloze zeilen."

31 "Wat was dat voor gezeik. Wat heb ik godverdomd met de hele shit te maken? Laat mij met rust." 32 "Je engagement met het wereldleed is tot een lachertje verworden: wat kan het jou in godsnaam nog schelen of Bosniërs wel of niet opgehouden zijn met Kroaten tot moes te schieten, of omgekeerd, of Palestijnen joden, of vice versa; wat kan het jou in godsnaam nog schelen dat dagelijks een hoop stomme negers blijven verhongeren; wat kan het jou in godsnaam nog schelen dat ultrarechts $z^{\prime} n$ opmars van 1933 aan het kopiëren is; wat kan het jou in godsnaam nog schelen wie de nieuwe president van Amerika wordt."

33 "Ach rot toch op zeikerd;" "Denk je dat ik daar één boterham met pindakaas minder om zal eten? Allicht wel, ik hou toch al niet van pindakaas."
} 
Not even the 2001 New York Twin Towers attacks drove him to adopt a political stance. Brusselmans observed in an interview: "Something like 11 September is obviously an important event. But how much sleep do you really lose over it? You follow things on TV for a while, but then your interest ebbs away pretty soon and you'd rather see a hot chick. That's how it is, isn't it?" (De Preter 2003). ${ }^{34}$ In Heilige schrik [Holy Fear, 2004] Brusselmans says this about himself: "I am a professional, full-time egoist and I'm proud of it" (Brusselmans 2004b: 8). ${ }^{35}$ This is an excellent characterization of the attitude that Brusselmans the author adopts with regard to (world) politics, although his emphatic lack of social engagement can of course also be viewed as a political gesture.

Only one subject, though, is close to Brusselmans's heart: cruelty to animals. In De kus in de nacht, for instance, he fulminates against the ill-treatment of animals that are infected with viral foot-and-mouth disease. When he sees on TV the cruelty with which the innocent animals are handled, he is ashamed of being human (Brusselmans 2002: 215). He experiences much the same feeling when he thinks about the ritual slaughter of lambs (Brusselmans 2004a: 9). This chronic compassion for animals can be traced to his youth - he is the son of a cattle dealer - and the horrors he claims to have witnessed as a child in the slaughterhouses. It makes him want to avenge himself. He would love to spit on people who are cruel to animals and push their faces into the mud (Brusselmans 2005b: 267-268). And elsewhere he says that such people should be clubbed to death (Brusselmans 2015: 378).

Over the past years Brusselmans's attitude as a "full-time egoist" appears to have undergone some change. It seems as if he, roused by current events, sees himself increasingly forced to sound a (more) engaged note and adopt more of a public intellectual's stance. This is especially true for one specific subject: the influence of Islam. It is, incidentally, mainly in his work that he does so, and then in typically Brusselmansesque manner, where it is not always clear whether he means what he writes. Is he being ironic, or isn't he? In this respect his stand resembles the stance taken by his idol Gerard Reve, who, it will be recalled, wrote about "splendid peoples," who should be put "on the chug-chug steamer" with a "bag full of mirrors and beads," "single ticket to Bushy Bushy Jungle, sir!" in De taal der liefde [The Language of Love, 1972]. ${ }^{36}$

In his unmistakeably fictitious novel De droogte [The Drought, 2003] Brusselmans for the first time touched upon the problems of the failure to integrate

\footnotetext{
34 “Zo'n 11 september is natuurlijk een belangwekkende gebeurtenis. Maar hoe lang lig jij daar echt wakker van? Je volgt het een tijdje op tv, maar al snel ebt je belangstelling weg en geef je de voorkeur aan een lekker wijf. Zo is het toch?".

35 "Ik ben een professionele, fulltime egoïst en daar ben ik trots op."

36 "prachtvolken;" "zak vol spiegeltjes en kralen op de tjoeki tjoeki stoomboot;" "enkele reis Takki Takki Oerwoud, meneer!" (Reve 1972: 71).
} 
Muslims. Its main character, Fazio, who comes across as a racist in the book, fears the growing presence of Islam:

You can't take three steps or you stumble over a turban, a veil or a banana skin. In two hundred years' time we'll be living here in jungle slums or in the Islamic lowlands, mark my words. Allah Akbar will be heard everywhere, and the sale of ashtrays will collapse because people only smoke water pipes. Everything Caucasian will be lying at the bottom of the Leie, its throat slit [...] Boy, am I glad I wasn't born a hundred years later. (Brusselmans 2001: 53) ${ }^{37}$

From that time onwards, other fictitious novels (without Herman Brusselmans as their main character) also have characters regularly levelling criticism at Islam. An example is Van drie tot zes [From Three to Six, 2011], where Willem Zundap lets fly at Muslims: "With these cloths on their heads, their beards and moustaches, their gibberish" (Brusselmans 2011: 46). ${ }^{38}$ Similarly, the main character in Guggenheimer koopt een neger [Guggenheimer Buys a Negro, 2017] rants and raves throughout the book about a hostile population group. Its members are called "Kwalafoten," who are undoubtedly meant to be taken for Muslims (Brusselmans 2017b).

Since 9/11 in the US, the assassination of Theo van Gogh and the increasing attention given to attacks, this subject has also featured in his (semi-)autobiographical novels, together with, obviously, the characteristic Brusselmansesque witticisms. Een dag in Gent [A Day in Ghent, 2008] illustrates this beautifully. I persona Herman Brusselmans remarks: "Me, I have the right to call Belgium a fucking shithole, but a fucking Muslim does not. And that stupid beard's got to go." Some pages later he remarks that he fears Muslims will take over the country within twenty-five years (Brusselmans 2008: 22, 30). ${ }^{39}$ To which he then adds:

Indeed, these Muslims. In Iran they hang homosexuals. [...] What they also do, Muslims, is beat up women because they are women. And hammering the idea into three-year-old children that everybody in the affluent West is an unbelieving dog that has to be killed by fire and sword. Another specialty: cutting off clitorises. If that is your specialty, you'd better take a look at yourself in the mirror and think to yourself: Jeez, what an

\footnotetext{
37 “Je kan geen drie stappen verzetten of je zou struikelen over een tulband, een sluier of een bananenschil. Over tweehonderd jaar leven we hier in de brousse of in de islamitische laagvlakten, let op m'n woorden. Het Allah Akbar zal niet uit de lucht zijn, en de asbakverkoop zal in elkaar stuiken omdat er toch alleen nog maar waterpijpen gerookt worden. Alles wat Kaukasisch is ligt met opengesneden keel op de bodem van de Leie [...] Tjonge, wat ben ik blij dat ik geen honderd jaar later geboren ben."

38 "Met die doeken op hun hoofd, hun baarden en snorren, hun brabbeltaaltje."

39 “Ík heb het recht om België een kutland te noemen, maar dat recht heeft zo'n moslim níet. En scheer die stomme baard af."
} 
arsehole. Western, democratic, capitalist society must defend itself, tooth and nail. (Brusselmans 2008: 39) ${ }^{40}$

This criticism of Islam is then subverted by the remark that he cannot really judge Muslims because he has never yet shared a bed with a Muslim woman (Brusselmans 2008: 158). His mingling of critical and humoristic comments makes it difficult to figure out where exactly Brusselmans himself stands - and that is exactly as he wants it to be.

Yet reading between the lines, it is actually possible to make out where he stands. In Kaloemmerkes in de zep he characterizes himself as a man with "leftist leanings," calling himself a "leftist intellectual." (Brusselmans 2009: 10, 17) ${ }^{41}$ And in one or two interviews he has similarly characterised himself as left-wing and progressive and as a socially-committed author who is concerned about the suffering in the world. It is not by chance that he is a member of Amnesty International (Van Velzen 2017). But this is not to say that he takes part in the debate as a public intellectual.

Until 2016. It was then - a week after the Islamist terrorist attacks at Zaventem airport and the Brussels metro station - that he published the column "Wij van links" [We on the Left] in the weekly HUMO. There he launched an attack on the Left's political correctness. The piece received a great deal of media attention. Allegedly a mouthpiece of the Left, he wrote in the irony-laden column that not so much the Muslims as "We on the Left" are guilty of the lack of integration. After all, Muslims are being discriminated against and treated as third-rate citizens: "And everything that goes wrong with the Muslims in this accursed West is our own fault" (Brusselmans 2016). ${ }^{42}$ The Bible is a "shit book," the Koran a masterpiece and Moroccan and Turkish food is delicious.

"We Westerners" are - have been since we led crusades against the East - oppressors, who have enslaved Muslims and still treat them badly. Of course, "We on the Left" want to bring in as many Orientals as we can, "for, oh yes, aren't they fun, and great, and peace-loving, and clever, and hospitable, and pleasant people to be with." That youths of foreign extraction may occasionally carry out raids, deal in drugs or call girls "whore" is our own fault. For "We on the Left" have failed to provide them with good education and proper social services. We have ourselves to blame for any attacks, like the ones on 9/11, in London, Paris and now in Brussels too, just as everything is our fault, according to Brusselmans.

\footnotetext{
40 “Tja, die moslims. In Iran hangen ze homoseksuelen op. [...] Wat ze ook doen, moslims, is vrouwen slaan omdat ze vrouwen zijn. En kinderen van drie inpeperen dat iedereen in het welvarende Westen een ongelovige hond is die moet worden afgemaakt met vuur en vlam. Nog zo'n specialiteit: clitorissen wegsnijden. Als dat je specialiteit is mag je toch wel 'ns in de spiegel kijken en denken: tjonge, wat een klootzak. De westerse, democratische, kapitalistische maatschappij moet zich met hand en tand verdedigen."

41 "linkse neigingen," "linkse intellectueel."

42 "En alles wat fout gaat met de moslims in dit vermaledijde Westen, is onze eigen schuld."
} 
These poor people have every right to blow themselves up with bags full of dynamite and nail bombs, killing as many "unholy" Westerners as possible. "We on the Left" must try to show understanding, however difficult this may be, Brusselmans says. It is only in the last line of his column that he lifts the veil of his irony as he writes: "We on the Left are digging our own grave, and some of us do it with a smile, too" (Brusselmans 2016). ${ }^{43}$

In response to this column, Brusselmans was immediately hailed as a hero of the right. The HUMO column was shared many times via the various social media. The (rightist) Dutch television channel Powned asked the author to read his piece in a broadcast, the item was shared on Facebook many times and met with much approval as well as criticism. The column also led to discussions in the more official channels.

In the weeks that followed, Brusselmans on several occasions returned to the matter in interviews. In HUMO he stated that he had not changed his mind and continued to see himself as a leftist. He had no problems with Syrian refugees and he explicitly wished to disassociate himself from politicians like Geert Wilders. Yet he was fiercely opposed to the political correctness that prevailed in the West, even towards ruthless, brutal IS attackers: "IS is an extremist group whose sole aim is conquest, who want to fuck up our western culture, with our miniskirts and our David Bowies. Then I, as the leftist thinker that I am, demand the right to stand up for my culture" (Van Tendeloo 2016). ${ }^{44}$

Looking back, the writer was surprised that his column had created such a stir. He received countless invitations to take part in debates with opponents, but he had no wish to do so: "Before you know it, you're a politician. And that is about the last thing I want to be." He added that he still adhered to his principle that literature is entertainment. Why is he now being taken serious all of a sudden while he never was before? Brusselmans himself believes it has to do with age: "When you have been working for 35 years, you become an eminence grise." It is a status he would rather not have: "I don't even want to be an authority. Or have a voice that is more important than somebody else's. I'm just an ordinary son of a bitch who happens to have written seventy books" (Cobbaert 2016). ${ }^{45}$ These last words provide the key to explaining the fact that Brusselmans's words caused such a stir.

\footnotetext{
43 "want ja, hoor, wat zijn ze toch leuk, en tof, en vredelievend, en slim, en gastvrij, en prettige mensen om mee om te gaan;" "Wij van links zijn bezig om ons eigen graf te graven, en sommigen van ons doen het nog met de glimlach ook."

44 “IS is een extremistische groepering, die uit is op verovering, die onze westerse cultuur, met onze korte rokjes en onze David Bowies, naar de kloten wil helpen. Dan eis ik, als linkse denker, het recht op om op te komen voor mijn cultuur."

${ }_{45}$ "Voor je het weet ben je een politieker. En dat is het laatste wat ik wil zijn;" "Als je 35 jaar bezig bent, word je een éminence grise;" "Ik wil helemaal geen autoriteit zijn. Of een stem hebben die belangrijker is dan die van iemand anders. Ik ben gewoon een boerenlul die toevallig zeventig boeken heeft geschreven."
} 


\section{Conclusion: From star author to public intellectual}

In this article Herman Brusselmans, author of seventy-five books, has been analysed as a star author. This term was coined by Joe Moran in his eponymous book published in 2000. Since that time, scientific interest in literary celebrity has increased but to this day, nothing has been written about the celebrity author Brusselmans. This is remarkable given the fact that, as mentioned in the introduction, he is the best known writer in the Dutch-language area. Even those who have never read any of his books, and never intend to, know him. His long hair and his bold, striking statements have made him a public figure.

What star author characteristics, then, have we encountered in Brusselmans? The first part of this article dealt with two of these, to begin with his high screen presence. Since the time, in the 1980s, that he started to present himself as a writer, he has constantly appeared on television. It would take a separate study to fully examine Brusselmans as a media personality. Here we have merely given a broad overview, but even this clearly brings out the fact that, even on television, he continually moves in two worlds, as he does in his work: highbrow and lowbrow alternate. His many media appearances have also resulted in great interest in his private life. The life of a star author is grist to the mill of gossip magazines.

Like many other star authors Brusselmans also thematises being famous in his literary work. Many of Brusselmans's books are about his life as a famous author. Wherever he goes, he is recognized, stared at, accosted and harassed. Since the 1990s (the impact of) his fame and the confrontation with fans and adversaries have been important themes for him. Describing his experience of celebrity which he, as we have seen, happily exaggerates - serves as a kind of marketing strategy to promote himself, and one that has proved to be quite successful, too. How powerful this self-created image is appears from the fact that even this aspect is mocked in a satirical TV programme.

In the last part of this article I have uncovered another effect of Brusselmans's star authorship. Despite his anti-engagement attitude and the opinion he expresses that literature merely serves to entertain, he has gradually developed into a cultural authority, precisely because of his public visibility. Brusselmans is a fascinating case study with which to illustrate this very process. When he wrote a political column in 2016 that lacked the usual silly high-jinks, this had an enormous impact. So it is that star author Herman Brusselmans acquired the status of a public intellectual, albeit reluctantly and temporarily. 


\section{Bibliography}

\section{Primary sources}

Brusselmans, Herman. 1988. Iedere zondag sterven en doodgaan in de week. Amsterdam: Prometheus. . 1991. Ex-schrijuer. Amsterdam: Prometheus. 1992. Het mooie kotsende meisje. Amsterdam: Prometheus.

1993. Ex-minnaar. Amsterdam: Prometheus. 1994. Ex-drummer. Amsterdam: Prometheus. 1996. Autobiografie van iemand anders. Amsterdam: Prometheus. 1997a. Logica voor idioten. Amsterdam: Prometheus. 1997b. Zul je mij altijd graag zien? Amsterdam: Prometheus. 1998. Bloemen op mijn graf. Amsterdam: Prometheus. 2000. Vergeef mij de liefde. Amsterdam: Prometheus. 2001. De droogte. Amsterdam: Prometheus. 2002. De kus in de nacht. Amsterdam: Prometheus. 2004a. Ik ben rijk en beroemd en ik heb nekpijn. Amsterdam: Prometheus. 2004b. Heilige schrik. Amsterdam: Prometheus. 2005a. Zijn er kanalen in Aalst? 4 ed. (Nieuw Verzameld Werk 5). Amsterdam: Prometheus.

2005b. Het spook van Toetegaai. Amsterdam: Prometheus.

2006a. Dagboek van een vermoeide egoïst. 3 ed. (Nieuw Verzameld Werk 6). Amsterdam: Prometheus.

. 2006b. Vlucht voor mij. 3 ed. (Nieuw Verzameld Werk 7). Amsterdam: Prometheus. 2008. Een dag in Gent. Amsterdam: Prometheus.

2009. Kaloemmerkes in de zep. Amsterdam: Prometheus.

2011. Van drie tot zes. Amsterdam: Prometheus.

2014. Poppy en Eddie. Amsterdam: Prometheus.

2015. Poppy en Eddie en Manon. Amsterdam: Prometheus.

29 March 2016. "Wij van links." Humo. 14 Dec. 2017. <http://www.humo.be/ humo-archief/362559/herman-brusselmans-wij-van-links>.

. 10 Apr. 2017(a). "Koppensneller: Het 17.412 $2^{\text {de }}$ kind is gestorven in Syrië." Humo. 14 Dec. 2017. <http://www.humo.be/humo-archief/376815/koppensneller-herman-brusselmans-het-17-412de-kind-is-gestorven-in-syrie>.

2017b. Guggenheimer koopt een neger. Amsterdam: Prometheus.

Reve, Gerard. 1972. De Taal der Liefde. 5 ed. Amsterdam: Athenaeum/Polak \& Van Gennep.

\section{Secondary sources}

Brysbaert, Marc, Paweł Mandera, and Emmanuel Keuleers. 2013. Naambekendheid van fictieschrijvers in Vlaanderen. Resultaten van de auteurstest 2013. Ghent University.

Chris \& Co. 22 Aug. 2014. "Herman Brusselmans en de teef." 14 Dec. 2017. <https:// www.youtube.com/watch? $v=k Q-p 8 c 9 B 94 E>$.

Cobbaert, Paul. 5 June 2016. “Herman Brusselmans, schrijver en sinds kort ook opiniemaker tegen wil en dank." De Zondag.

Dijksman, Daan. 31 July 2010. “Die programma's moeten ook vol." Het Parool. 
Eeden, Ed van. 2012. Alles oké? Nee. 55 jaar Herman, 30 jaar schrijuerschap. Amsterdam: Prometheus.

Franssen, Gaston and Rick Honings. 2016. "Introduction: Starring the Author." Celebrity Authorship and Afterlives in English and American Literature. Eds. Gaston Franssen and Rick Honings. Basingstoke: Palgrave Macmillan. 1-21. . 2017. "Idolizing Authorship: An Introduction." Idolizing Authorship. Literary Celebrity and the Construction of Identity, 1800 to the Present. Eds. Gaston Franssen and Rick Honings. Amsterdam: Amsterdam University Press. 11- 27

Hendrickx, Wilfried. 30 June 1988. “Billen Bloot. De auteur: 'Mijn levensverwachting ligt laag.'" Humo.

Heynders, Odile. 2012. "Strijd in voetnoten. Grunberg op de voorkant van de Volkskrant." Strijd! Polemiek en conflict in de Nederlandse letteren. Eds. Suzanne Fagel, Eep Francken, and Rick Honings. Leiden: Leiden University Press. 223-229.

. 2016. Writers as Public Intellectuals. Literature, Celebrity, Democracy. Basingstoke: Palgrave Macmillan.

Honings, Rick. 2016. De dichter als idool. Literaire roem in de negentiende eeuw. Amsterdam: Bert Bakker.

2017. Majoor van het Menselijk Leed. Leven en werk van Herman Brusselmans. Amsterdam: Prometheus.

Hupe, Katharina. 2016. “Defamation Trials in Belgium - The Case of Herman Brusselmans's Novel Uitgeverij Guggenheimer." Literary Trials. Exceptio Artis and Theories of Literature in Court. Ed. Ralf Grüttemeier. London: Bloomsbury Academic. 159-174.

Krieken, Robert van. 2012. Celebrity Society. London: Routledge.

Maris, Jeroen. 11 Feb. 2014. "Herman Brusselmans. Interview." Humo.

Moran, Joe. 2000. Star Authors. Literary Celebrity in America. London: Pluto Press.

Preter, Jeroen De. 3 Sept. 2003. "Herman Brusselmans ontmoet zijn grootste fan." De Morgen.

Rogiers, Filip and Steven Heene. 2 Apr. 1998. "Hier rust Herman Brusselmans." De Morgen.

Takken, Wilfred. 5 Nov. 1999. "Ik ben wellevend van nature. [Interview with Herman Brusselmans]." NRC Handelsblad.

Tendeloo, Hanne van. 5 Apr. 2016. "Herman Brusselmans, de nieuwe held van rechts." Humo.

Vakmansklap. 12 March 2017. “Interview with Herman Brusselmans." 14 Dec. 2017. <https://www.youtube.com/watch?v=Yq1R7wwxrA0>.

Velzen, Joost van. 26 Jan. 2017. "Brusselmans: Liefde en letteren wakkeren elkaar aan." Trouw.

Verhulst, Dimitri. 24 Aug. 2001. “Doch dit terzijde." HP/De Tijd. 